\title{
Abscisic acid-deficient sit tomato mutant responses to cadmium-induced stress
}

\author{
Georgia B. Pompeu ${ }^{1}$ - Milca B. Vilhena ${ }^{1}$ - Priscila L. Gratão ${ }^{2} \cdot$ Rogério F. Carvalho $^{2}$ • \\ Mônica L. Rossi ${ }^{3}$ - Adriana P. Martinelli ${ }^{3}$. Ricardo A. Azevedo ${ }^{1}$
}

Received: 16 February 2016 / Accepted: 23 May 2016 /Published online: 4 June 2016

(C) Springer-Verlag Wien 2016

\begin{abstract}
There is a very effective cross-talk between signals triggered by reactive oxygen species and hormonal responses in plants, activating proteins/enzymes likely to be involved in stress tolerance. Abscisic acid (ABA) is known as a stress hormone that takes part in the integration of signals. This work aimed to characterize the biochemical response and ultrastructural changes induced by cadmium $(\mathrm{Cd})$ in the Micro-Tom (MT) sitiens ABA-deficient mutant (sit) and its wild-type (MT) counterpart. MT and sit plants were grown over a 96-h period in the presence of $\mathrm{Cd}\left(0,10\right.$, and $\left.100 \mu \mathrm{M} \mathrm{CdCl}_{2}\right)$. The overall results indicated increases in lipid peroxidation, hydrogen peroxide content and in the activities of the key antioxidant enzymes such as catalase, glutathione reductase, and ascorbate peroxidase in both genotypes. On the other hand, no alteration was observed in chlorophyll content, while the activity of another antioxidant enzyme, superoxide dismutase, remained constant or even decreased in the presence of $\mathrm{Cd}$. Roots and shoots of the sit mutant and MT were analyzed by light and transmission electron microscopy in order to characterize the structural changes caused by the exposure to this metal. Cd caused a decrease in intercellular spaces in shoots and a decrease in cell size in roots of both genotypes. In
\end{abstract}

Handling Editor: Néstor Carrillo

Ricardo A. Azevedo

raa@usp.br

1 Departamento de Genética, Escola Superior de Agricultura Luiz de Queiroz-ESALQ, Universidade de São Paulo-USP,

13418-900 Piracicaba, SP, Brazil

2 Departamento de Biologia Aplicada à Agropecuária, Faculdade de Ciências Agrárias e Veterinárias-FCAV, Universidade Estadual Paulista-UNESP, 14884-900 Jaboticabal, SP, Brazil

3 Centro de Energia Nuclear na Agricultura-CENA, Universidade de São Paulo-USP, 13400-970 Piracicaba, SP, Brazil leaves, Cd affected organelle shape and internal organization of the thylakoid membranes, whereas noticeable increase in the number of mitochondria and vacuoles in MT and sit roots were observed. These results add new information that should help unravel the relative importance of ABA in regulating the cell responses to stressful conditions induced by $\mathrm{Cd}$ apart from providing the first characterization of this mutant to oxidative stress.

Keywords Oxidative stress $\cdot$ Phytohormones $\cdot$ Reactive oxygen species $\cdot$ Root and leaf anatomy $\cdot$ Solanum lycopersicum $\cdot$ Ultrastructure

\section{Introduction}

Cadmium $(\mathrm{Cd})$ is a non-essential element, being considered the most toxic among the heavy metals, negatively affecting plant metabolism mainly by inducing an oxidative stress condition (Cuypers et al. 2010; Dourado et al. 2013, 2015; Gratão et al. 2015). Cd is naturally present in the environment in trace concentrations, or can be introduced through anthropogenic activities, such as the use of fertilizers, pesticides, and industrial and domestic effluents, being absorbed by plants from contaminated soil or water (Al-Khateeb and Al-Qwasemeh 2014; Su et al. 2014). Recently, the use of nanoparticles containing heavy metal elements in commercial products and industrial applications has significantly increased and raised concerns on their adverse effects on human and environmental health (Arruda et al. 2015). Moreover, Cd has high mobility in the soil-plant system affecting biochemical mechanisms by reducing the redox balance control, causing plasma membrane rupture, which culminates in loss of its function (Gallego et al. 2012; Iannone et al. 2015). This metal can also induce serious disturbances in physiological processes such as 
photosynthesis, respiration, plant-water relations, mineral uptake, among others (López-Chuken and Young 2010; Gill et al. 2012), leading to reduced plant growth or even cell death (Shekhawat et al. 2010; Hu et al. 2013; Moradi and Ehsanzadeh 2015).

Structural changes have also been associated with $\mathrm{Cd}$ accumulation in plant tissues (Vitória et al. 2003, 2006; Maksimović et al. 2007; Gratão et al. 2009; Lux et al. 2011; Mondal et al. 2013). Structural disorganization in leaves, reduced intercellular spaces, altered thylakoid structure, wilted epidermis, thinner cell walls, cytoplasm condensation due to increase in matrix density, mitochondrial cristae reduction, high level of chromatin condensation, nuclear envelope disruption, mitotic index decrease, and chromosomal aberrations have been observed for a wide range of plant species (Djebali et al. 2005; Vitória et al. 2006; Gratão et al. 2009; Ali et al. 2013a, b).

The molecular oxygen $\left(\mathrm{O}_{2}\right)$ naturally present in cells promotes the production of reactive oxygen species (ROS) such as superoxide radical $\left(\mathrm{O}_{2}{ }^{-}\right)$, singlet oxygen $\left({ }^{1} \mathrm{O}_{2}\right)$, hydrogen peroxide $\left(\mathrm{H}_{2} \mathrm{O}_{2}\right)$, and hydroxyl radicals $(\mathrm{OH} \bullet)$, which are continuously produced by cells in plants and other organisms under normal or stressful conditions (Peters et al. 2014). Metals can enhance ROS production, which react with several cellular compounds, leading to damage to the cell system and even cell death (Gratão et al. 2015).

The cell redox balance may be maintained through the action of antioxidant mechanisms, which are capable, depending on the level of the stress, of preventing uncontrolled oxidation through the removal of ROS (Azevedo et al. 2011; Hippler et al. 2015). These mechanisms may involve enzymatic and/or nonenzymatic systems. The enzymatic mechanisms of ROS scavenging include the action of a number of enzymes, such as superoxide dismutase (SOD), which catalyzes $\mathrm{O}_{2} \cdot{ }^{-}$into $\mathrm{H}_{2} \mathrm{O}_{2}$ (Gratão et al. 2008a). Subsequently, $\mathrm{H}_{2} \mathrm{O}_{2}$ may be detoxified into $\mathrm{H}_{2} \mathrm{O}$ by ascorbate peroxidase (APX) and catalase (CAT), among other peroxidases (Wu et al. 2015). The nonenzymatic antioxidants include ascorbic acid and glutathione, as well as vitamins, flavonoids, alkaloids, and carotenoids (Gratão et al. 2005; Alcântara et al. 2015). Reduced glutathione (GSH) is oxidized to glutathione (GSSG), whereas ascorbate is oxidized into monodehydroascorbate (MDHA) and dehydroascorbate (DHA). Through the ascorbate-glutathione cycle, GSSG, MDHA, and DHA may be reduced and form GSH and ascorbate again (Nogueirol et al. 2015).

It is also known that oxidative stress is highly controlled by plant hormones and there are many studies showing the interaction between ROS and/or antioxidants and plant hormones (Gratão et al. 2012; Monteiro et al. 2011, 2012; Carvalho et al. 2013; Cai et al. 2015; Schellingen et al. 2015; Soares et al. 2016). Although these multiple stress responses are essential for plant survival under heavy metal-stress conditions, the exact role of phytohormones in these responses is still not clear, especially the cross-talk among ROS, phytohormones and antioxidant systems (Asgher et al. 2015).

MT plants feature genetic variations and natural hormonal mutations, such as the deficiency in functional enzyme activity at the final step in abscisic acid (ABA) biosynthesis observed in the hormonal mutant sit (Taylor et al. 1988; Mäkelä et al. 2003; Harrison et al. 2011). ABA is often referred as a stress hormone due to its main involvement in biotic stress responses (Harrison et al. 2011). Therefore, plants can constantly adjust ABA levels in response to physiological and environmental changes, especially from root signaling (Cutler et al. 2010). ABA can also be accumulated in roots when subjected to external stresses such as drought, salinity, and nutrient deficiency (or excess), serving as a long distance signal to regulate many adaptive responses in plants, such as compatible solutes accumulation, root modification, stomatal closure, and induction of the antioxidative stress system (Hartung et al. 2005). Therefore, it is not surprising that $\mathrm{ABA}$ is also involved in the stress response to heavy metals contamination. For example, Shi et al. (2015) has recently shown that ABA was able to alleviate zinc toxicity in poplar (Populus $\times$ canescens; syn. Populus tremula $\times$ P. alba). ABAsignaling genes, such as $P Y L s$, were generally sensitive during copper stress in cucumber (Cucumis sativus) (Wang et al. 2014). ABA has also been shown as a component of stress response induced by $\mathrm{Cd}$. In fact, $\mathrm{ABA}$ induced tolerance in wheat (Triticum aestivum) seedlings subjected to Cd stress (Han et al. 2012), while potato (Solanum tuberosum) exposed to Cd exhibited increased ABA content (Stroiński et al. 2013).

In this study, we tried to further explore the interaction between $\mathrm{ABA}$ and $\mathrm{Cd}$ in tomato plants, which is the most important vegetable crop species in the world. The Micro Tom sitiens ABA-deficient mutant (sit) and its wild-type (MT) counterpart were used to characterize the biochemical and ultrastructural changes induced by $\mathrm{Cd}$ toxicity. As far as we know, the response of this mutant to heavy metals-induced stress has never been reported.

\section{Materials and methods}

Seeds of tomato (Solanum lycopersicum L.) cv Micro-Tom (MT) and MT sitiens ABA-deficient mutant (sit) were sown in trays containing vermiculite supplemented with Hoagland and Arnon (1950) nutrient solution at $20 \%$ ionic strength. After 30 days the tomato plants were transferred to 12-L trays containing Hoagland's nutrient solution at $10 \%$. This system is similar to a greenhouse hydroponic system used by tomato producers and was previously reported by Piotto et al. (2014) in a system for the isolation of Cd-resistant mutants. The nutrient concentrations were increased daily for 3 days to allow plant adaptation. On the fourth day, before $\mathrm{Cd}$ addition, the nutrient solution was changed to $50 \%$ ionic strength. 
Chlorophyll measurements were carried out in MT and sit mutant leaves. Roots and shoots were then collected, rinsed in distilled water and stored at $-80^{\circ} \mathrm{C}$ for further biochemical analysis (T0). Subsequently, the solution was supplemented with 0,10 , and $100 \mu \mathrm{M} \mathrm{CdCl}_{2}$. These concentrations were chosen based on previous results with MT from our research group (Gratão et al. 2009, 2012; Monteiro et al. 2011). Ninetysix hours after $\mathrm{Cd}$ addition, leaves were used for chlorophyll measurements and then, roots and shoots were collected, rinsed in distilled water and stored at $-80{ }^{\circ} \mathrm{C}$ for further biochemical analysis.

\section{Dry weight and Cd concentration determination}

Ninety-six hours after $\mathrm{Cd}$ addition to the nutrient solution, plants were collected, separated into shoots and roots, and dried in a forced-air oven at $65{ }^{\circ} \mathrm{C}$ for $72 \mathrm{~h}$, when the dry weight was recorded. $\mathrm{Cd}$ concentration in roots and shoots was determined by digestion with a mixture of nitric and perchloric acids as described by Malavolta et al. (1997), followed by a quantitative analysis using a flame atomic absorption spectroscopy with a Perkin Elmer spectrometer, model 310. Cd concentrations were expressed in milligram of $\mathrm{Cd}$ per gram dry weight.

\section{Chlorophyll content determination}

A Minolta SPAD-502 meter, which measures leaf transmittance at two wavelengths, red (660 nm, approximately) and near infrared (940 nm, approximately), was used to determine the leaf chlorophyll content. SPAD readings were taken weekly on the terminal leaflet of the fourth leaf from the base of the shoot. The SPAD sensor was randomly placed on the leaf mesophyll tissue, avoiding the veins (Monteiro et al. 2011).

\section{Lipid peroxidation}

Lipid peroxidation was determined by estimating the content of thiobarbituric acid reactive substance (TBARS). This method was modified as follows: $200 \mathrm{mg}$ of roots and shoots were grounded in a mortar under liquid nitrogen and homogenized in a solution containing $0.1 \%(v / v)$ trichloroacetic acid (TCA) and $20 \%(w / v)$ insoluble polyvinylpolypyrrolidone (PVPP). The homogenate was centrifuged at $10,000 \times g$ for $10 \mathrm{~min}$, and then $250 \mu \mathrm{L}$ of the supernatant were added to a solution composed of $1 \mathrm{~mL}$ of $0.5 \%(v / v)$ 2-thiobarbituric acid (TBA) plus $20 \%(v / v)$ TCA. The mixture was incubated in a dry bath at $95{ }^{\circ} \mathrm{C}$ for $30 \mathrm{~min}$. The homogenate was placed in an ice bath, maintained for $10 \mathrm{~min}$, and centrifuged at $10,000 \times \mathrm{g}$ for $10 \mathrm{~min}$ to separate the residues formed during the heating process. Malondialdehyde (MDA) was monitored by measurements at 535 and $600 \mathrm{~nm}$ and the concentration calculated using an extinction coefficient of $1.55 \times 10^{-5} \mathrm{~mol}^{-1} \mathrm{~cm}^{-1}$. MDA content was expressed in nmol $\mathrm{g}^{-1}$ fresh weight (Arruda et al. 2013).

\section{Hydrogen peroxide content determination}

Samples of roots and shoots from each treatment were macerated in liquid nitrogen and homogenized in $0.1 \%(w / v)$ TCA. The homogenate was centrifuged at $10,000 \times \mathrm{g}$ for $20 \mathrm{~min}$ at $4^{\circ} \mathrm{C}$, and then $200 \mu \mathrm{L}$ of $100 \mathrm{mM}$ potassium phosphate buffer $(\mathrm{pH} 7.0)$ and $800 \mu \mathrm{L}$ of $1 \mathrm{M}$ potassium iodide (KI) were added. The reaction medium was maintained in the dark in an ice bath for $1 \mathrm{~h}$. The absorbance was then read at $390 \mathrm{~nm}$. The hydrogen peroxide $\left(\mathrm{H}_{2} \mathrm{O}_{2}\right)$ content was determined using $\mathrm{H}_{2} \mathrm{O}_{2}$ as a standard (Rendón et al. 2013).

\section{Antioxidant enzymes activities determination}

For enzyme extraction and protein determination, roots and shoots samples were homogenized in buffer volume/fresh weight $(2: 1)$ in a mortar with a pestle in $100 \mathrm{mM}$ potassium phosphate buffer ( $\mathrm{pH} 7.5$ ) containing $1 \mathrm{mM}$ ethylenediaminetetraacetic acid (EDTA), $3 \mathrm{mM}$ DTT, and $4 \%(w / v)$ insoluble PVPP. The homogenate was centrifuged at $10,000 \times \mathrm{g}$ for $30 \mathrm{~min}$, and the supernatant was stored in separate aliquots at $-80{ }^{\circ} \mathrm{C}$. All steps were carried out at $4{ }^{\circ} \mathrm{C}$ unless stated otherwise (Gratão et al. 2012). Protein concentration for all samples was determined by the method of Bradford (1976), using bovine serum albumin as a standard.

\section{Catalase (CAT, EC 1.11.1.6)}

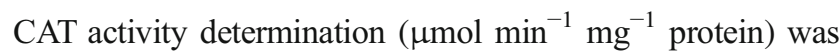
assayed at $25{ }^{\circ} \mathrm{C}$ in a reaction mixture containing $1 \mathrm{~mL}$ $100 \mathrm{mM}$ potassium phosphate buffer $(\mathrm{pH} 7.5)$ and $25 \mu \mathrm{L}$ $\mathrm{H}_{2} \mathrm{O}_{2}$ (30\% solution). The reaction was initiated by the addition of $25 \mu \mathrm{L}$ of protein extract, and the activity determined by following the decomposition of $\mathrm{H}_{2} \mathrm{O}_{2}$ as changes in absorbance at $240 \mathrm{~nm}$, over $1 \mathrm{~min}$ (Monteiro et al. 2011).

\section{Glutathione reductase (GR, EC 1.6.4.2)}

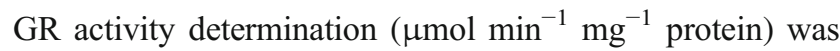
carried out spectrophotometrically at $30{ }^{\circ} \mathrm{C}$ in a mixture consisting of $1 \mathrm{~mL} 100 \mathrm{mM}$ potassium phosphate buffer

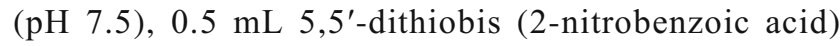
(DTNB) $3 \mathrm{mM}, 0.1 \mathrm{~mL}$ NADPH $2 \mathrm{mM}, 0.1 \mathrm{~mL}$ GSSG 
$20 \mathrm{mM}$, and $50 \mu \mathrm{L}$ of protein extract. The reduction rate of oxidized glutathione was followed by monitoring the change in absorbance at $412 \mathrm{~nm}$ over $1 \mathrm{~min}$ (Carvalho et al. 2013).

\section{Ascorbate peroxidase (APX, EC 1.11.1.11)}

APX activity ( $\mu \mathrm{mol} \mathrm{min}{ }^{-1} \mathrm{mg}^{-1}$ protein) was determined by the addition of $40 \mu \mathrm{L}$ protein extract to $1 \mathrm{~mL}$ of a solution containing $50 \mathrm{mM}$ ascorbate, $0.1 \mathrm{mM}$ EDTA, and $0.1 \mathrm{mM}$ $\mathrm{H}_{2} \mathrm{O}_{2}$. The oxidation rate was monitored at $290 \mathrm{~nm}$, at $30{ }^{\circ} \mathrm{C}$, over a period of $1 \mathrm{~min}$ (Dourado et al. 2015).

\section{Superoxide dismutase (SOD, EC 1.15.1.1) non-denaturing PAGE assay activity}

Polyacrylamide gel electrophoresis (PAGE) analysis was carried out under non-denaturing conditions in $12 \%$ polyacrylamide gels, followed by SOD activity staining as described by Vitória et al. (2001), with equal amounts of protein $(40 \mu \mathrm{g})$ being loaded onto each gel lane. Electrophoresis buffers and gels were prepared as described by Vitória et al. (2001), except that SDS was excluded. To perform SOD activity staining, after nondenaturing-PAGE separation, the gel was rinsed in distilled water and incubated in the dark in $50 \mathrm{mM}$ potassium phosphate buffer $(\mathrm{pH}$ 7.8) containing $0.05 \mathrm{mM}$ riboflavin, $1 \mathrm{mM}$ EDTA, $0.1 \mathrm{mM}$ nitrobluetetrazolium, and $0.3 \% \mathrm{~N}, \mathrm{~N}, \mathrm{~N}^{\prime}, \mathrm{N}^{\prime}$-tetramethylethylenediamine. After $30 \mathrm{~min}$, the gels were rinsed with distilled water and then illuminated in water until the achromatic bands of SOD activity were visible on a purple-stained gel. The SOD isoenzymes were distinguished by their sensitivity to inhibition by $2 \mathrm{mM}$ potassium cyanide and $5 \mathrm{mM}$ hydrogen peroxide. One unit of bovine liver SOD (Sigma, St. Louis, MO, USA) was used as a positive control of activity (Barbosa et al. 2012).

\section{Light and transmission electron microscopy}

For histological characterization samples were processed for light (LM) and transmission electron microscopy (TEM). Root tips and leaf blade were collected after 20 days of supplementation with 0,10 , and $100 \mu \mathrm{M} \mathrm{CdCl}_{2}$. Samples were immediately fixed in a modified Karnovsky solution (Karnovsky 1965) (2\% glutaraldehyde, $2 \%$ paraformaldehyde, and $5 \mathrm{mM} \mathrm{CaCl}_{2}$ in $0.05 \mathrm{M}$ sodium cacodylate buffer, $\mathrm{pH}$ 7.2) for $48 \mathrm{~h}$. The samples were then rinsed in cacodylate buffer $(0.1 \mathrm{M})$ and post fixed in $1 \%$ osmium tetroxide in $0.1 \mathrm{M}$ sodium cacodylate buffer, $\mathrm{pH} 7.2$, at room temperature, for $1 \mathrm{~h}$. The samples were dehydrated in a graded acetone series and embedded in Spurr epoxy resin (EMS, Electron Microscopy Sciences, Hatfield, PA, USA), for $48 \mathrm{~h}$. Semithin sections $(120-200 \mathrm{~nm})$ were collected in glass slides, stained with toluidine blue ( $2 \%$ in water) for $5 \mathrm{~min}$, rinsed in distilled water, and air-dried. The sections were permanently mounted in Entellan ${ }^{\circledR}$, observed and documented using an upright light microscope (LMD 7000, Leica, Germany). Ultra-thin sections $(60-90 \mathrm{~nm})$ of leaves and roots were collected on copper grids (300 mesh), and stained with uranyl acetate $(2.5 \%)$, followed by lead citrate $(0.1 \%)$ (Reynolds 1963). Sections were observed at $80 \mathrm{kV}$ under a transmission electron microscope (JEM 1400 JEOL, Tokyo, Japan), and the images digitalized.

\section{Statistical analysis}

The experimental design was completely randomized and the results expressed as the mean and standard error $( \pm \mathrm{SE})$ of three independent replicates of each extract for plant growth, $\mathrm{Cd}$ accumulation, dry weight, lipid peroxidation, $\mathrm{H}_{2} \mathrm{O}_{2}$ content, chlorophyll content, CAT, GR and APX activities. The statistical analysis was performed using the SASM-Agri software version 8.2. Tukey test was used for multiple means comparison, followed by individual ANOVA for each character, at a 0.05 level of significance.

\section{Results}

After 96-h of exposure to Cd, MT plants cultivated in 10 and $100 \mu \mathrm{M} \mathrm{CdCl}_{2}$ exhibited differences in plant growth in comparison to the control $\left(0 \mu \mathrm{M} \mathrm{CdCl}_{2}\right)$ and plants collected before $\mathrm{Cd}$ addition ( $\mathrm{T} 0$ ). Root biomass was slightly increased in MT at $100 \mu \mathrm{M} \mathrm{CdCl}_{2}$, when compared to the other treatments and controls (Fig. 1a). Shoot biomass, in both treatments (10 and $100 \mu \mathrm{M} \mathrm{CdCl}_{2}$ ), were significantly increased when compared to the control and T0 (Fig. 1b). Mutant (sit) plants cultivated in solution with $\mathrm{CdCl}_{2}$ did not exhibit differences in root and shoot growth in comparison to the control without $\mathrm{CdCl}_{2}$ and $\mathrm{T} 0$.

$\mathrm{Cd}$ accumulation in the plants was proportional to the metal concentration added to the nutrient solution (Fig. 1). At the concentration of $100 \mu \mathrm{M} \mathrm{CdCl}$, sit roots absorbed higher amounts of $\mathrm{Cd}$ when compared to MT roots (Fig. 1c). Similar amounts of $\mathrm{Cd}$ were transported to shoots of genotypes grown in both metal concentrations (Fig. 1d). The chlorophyll content in shoots of MT and sit grown in the presence or absence of Cd did not differ (Fig. 2).

MDA concentration varied when plants were exposed to $\mathrm{Cd}$, both in shoots and roots of MT and sit (Fig. 3). Mutant (sit) roots exhibited higher levels of lipid peroxidation when compared to MT roots (Fig. 3a). MDA levels were higher at the 
Fig. 1 Dry weight $(\mathbf{a}, \mathbf{b})$ and $\mathrm{Cd}$ accumulation $(\mathbf{c}, \mathbf{d})$ of roots and shoot of Micro-Tom (MT) and sitiens (sit) plants grown over a 96-h period and treated with 10 or $100 \mu \mathrm{M} \mathrm{CdCl}_{2}$ or not treated $(0 \mu \mathrm{M})$. T0 represents plants collected before addition of $\mathrm{CdCl}_{2}$. Values are the means of three replicates \pm SE. Different letters indicate significant difference at $p<0.05$
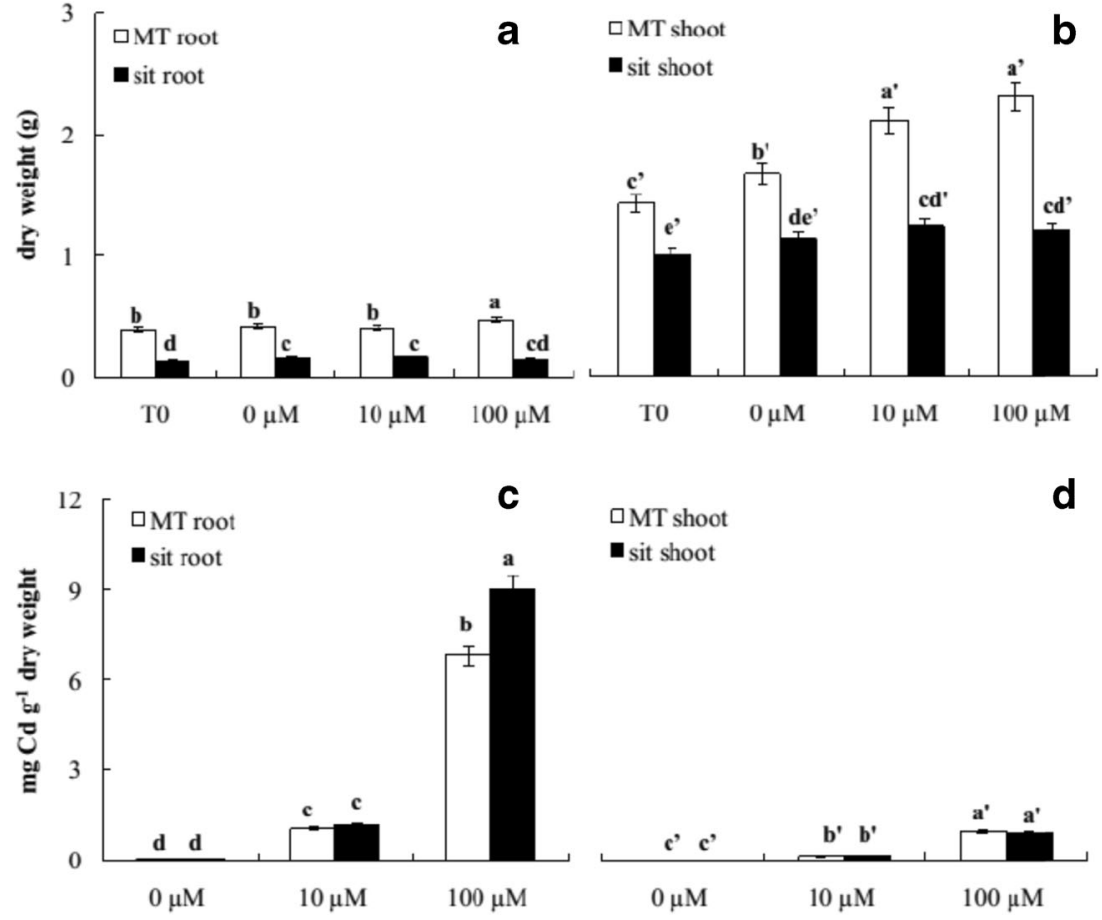

Cd concentration

concentration of $100 \mu \mathrm{M} \mathrm{CdCl}_{2}$. Shoots of MT and sit exhibited similar values of lipid peroxidation (Fig. 3b). Differences in $\mathrm{H}_{2} \mathrm{O}_{2}$ content were observed in roots and shoots of MT and sit plants exposed to $\mathrm{Cd}$ (Fig. 3). The concentration of $100 \mu \mathrm{M} \mathrm{CdCl}_{2}$ induced an increase in $\mathrm{H}_{2} \mathrm{O}_{2}$ production, mainly in the roots, in both genotypes (Fig. 3c). An increase in $\mathrm{H}_{2} \mathrm{O}_{2}$ content in shoots of MT and sit plants exposed to $\mathrm{Cd}$ was also observed (Fig. 3d).

SOD activity in roots and shoots of MT and sit plants was determined based on the isoenzymes separation by nondenaturing PAGE (Fig. 4). SOD isoenzymes were detected and characterized as Mn/SOD (SOD I and II) and Fe/SOD (SOD III) (data not shown). Roots and shoots of MT and sit exhibited decrease in SOD I activity (Fig. 4a, b). In shoots of MT, SOD II and III activities decreased in the presence of Cd (Fig. 4a, lanes 1, 2, and 3), but in the shoots of the sit mutant SOD II and III exhibited similar levels of activity (Fig. 4a, lanes 4, 5, and 6). No alterations were observed in SOD activity in roots of both genotypes grown in nutrient solution with both Cd concentrations (Fig. 4b).

CAT activity in roots and shoots of MT and sit was determined spectrophotometrically (Fig. 5). At T0, roots of sit and shoots of MT exhibited high activity of this enzyme (Fig. 5a, b). Roots of MT and sit exhibited small differences in CAT activity when exposed to 0 and $10 \mu \mathrm{M} \mathrm{CdCl}$, however, the highest CAT activity encountered was observed in roots at the highest metal concentration for both genotypes (Fig. 5a). Shoots of MT and sit exhibited high CAT activity increase when exposed to 10 and $100 \mu \mathrm{M} \mathrm{CdCl}_{2}$ (Fig. 5b).
$\mathrm{Cd}$ induced increase in GR activity in roots of MT and sit (Fig. 5). The highest activity was observed in MT roots exposed to $10 \mu \mathrm{M} \mathrm{CdCl}_{2}$ (Fig. 5c). The shoot of sit exhibited increased GR activity when exposed to the concentration of $100 \mu \mathrm{M} \mathrm{CdCl}_{2}$ (Fig. 5d). The highest APX activities (Fig. 5) were observed in roots and shoot of both, MT and sit plants, in the presence of $\mathrm{Cd}$. Roots exhibited increased APX activity at 100 and $10 \mu \mathrm{M} \mathrm{CdCl}_{2}$, for MT and sit, respectively (Fig. 5e). The enzyme activity in shoot increased with $\mathrm{Cd}$, irrespective of the genotypes analyzed (Fig. 5f).

Anatomical and ultrastructural analyses of roots and leaves of MT and sit exposed to 0,10 , and $100 \mu \mathrm{M} \mathrm{CdCl} \mathrm{Cl}_{2}$ were

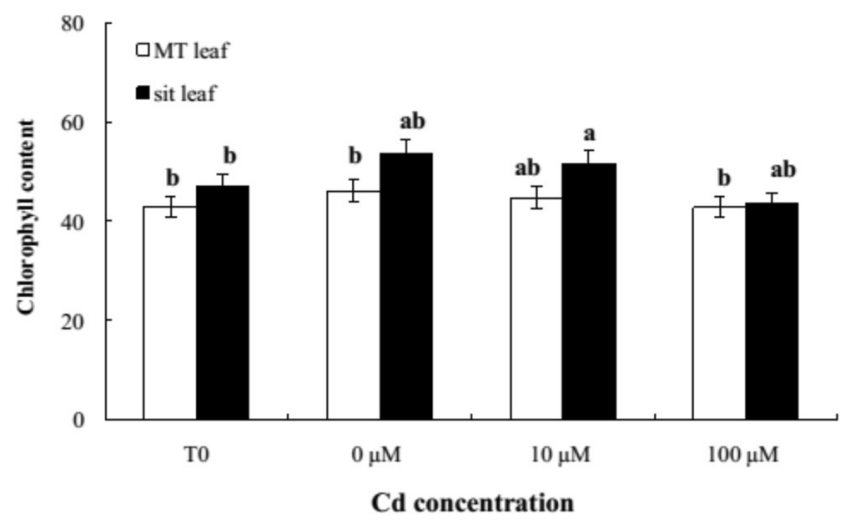

Fig. 2 Chlorophyll content measured (SPAD units) in leaves of Micro Tom (MT) and sitiens (sit) in plants grown over a 96-h period in the presence of 10 and $100 \mu \mathrm{M} \mathrm{CdCl}_{2}$ or not treated $(0 \mu \mathrm{M})$. T0 represents plants collected before addition of $\mathrm{CdCl}_{2}$. Values are the means of three replicates $\pm \mathrm{SE}$. Different letters indicate significant difference at $p<0.05$ 
Fig. 3 Lipid peroxidation measured as malondialdehyde (MDA) content (nmol MDA $\mathrm{g}^{-1}$ fresh weight) in roots (a) and shoots (b) of Micro-Tom (MT) and sitiens (sit) plants and hydrogen peroxide $\left(\mathrm{H}_{2} \mathrm{O}_{2}\right)$ content $\left(\mu \mathrm{mol} \mathrm{H}_{2} \mathrm{O}_{2} \mathrm{~g}^{-1}\right.$ fresh weight) in roots (c) and shoots (d) of MT and sit plants grown over a 96-h period in the presence of 10 and $100 \mu \mathrm{M} \mathrm{CdCl}$ or not treated $(0 \mu \mathrm{M})$. T0 represents plants collected before addition of $\mathrm{CdCl}_{2}$. Values are the means of three replicates $\pm \mathrm{SE}$. Different letters indicate significant difference at $p<0.05$

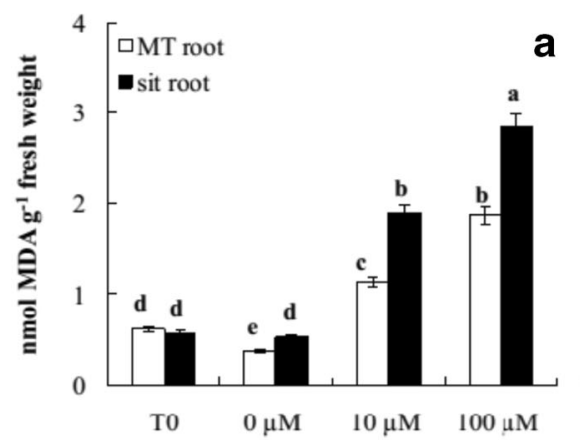

口MT shoot

b

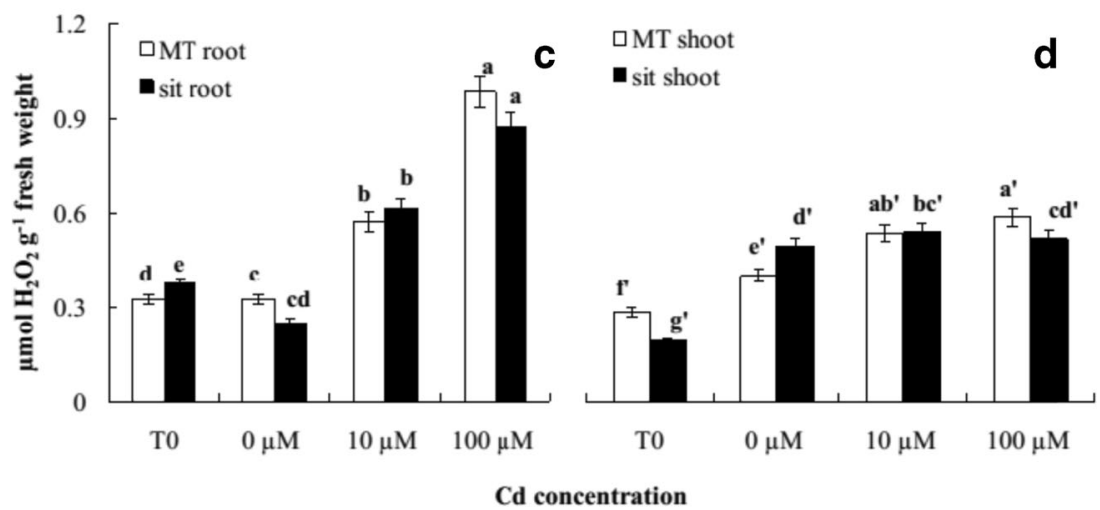

performed in plants grown in nutrient solution, and exposed to $\mathrm{Cd}$ over a period of 20-days. Histological sections observed under light microscopy (LM) revealed anatomical differences between MT and sit exposed to 10 and $100 \mu \mathrm{M} \mathrm{CdCl}_{2}$ (Figs. 6 and 7). A decrease in intercellular spaces and leaf area in the leaves in the presence of $\mathrm{Cd}$ for both genotypes, and an increase in cell size, especially in the palisade parenchyma, were observed when compared to the control (Fig. 6b, c, e, f). In the roots, MT and sit exhibited cell size reduction in the presence of the metal in both concentrations tested (Fig. 7b, c, e, f).
Ultrastructural analysis of root samples of plants grown in 10 and $100 \mu \mathrm{M} \mathrm{CdCl}_{2}$ revealed an increased number of mitochondria (Fig. 8, white arrows). Ultrastructural changes in mitochondria shape (Fig. 8b, c, e, f, k, l) and increase in vacuole number (more in roots of MT than in sit roots) (Fig. 8e, f) were also detected. No alterations were observed in the nuclear membrane and cell wall (Fig. 8b, e, k, 1). In leaves of MT and sit plants exposed to 10 and $100 \mu \mathrm{M} \mathrm{CdCl}_{2}$, disorganization in the internal structures of chloroplasts was observed (Fig. 9b, c, e, f). Thylakoid membrane and grana were
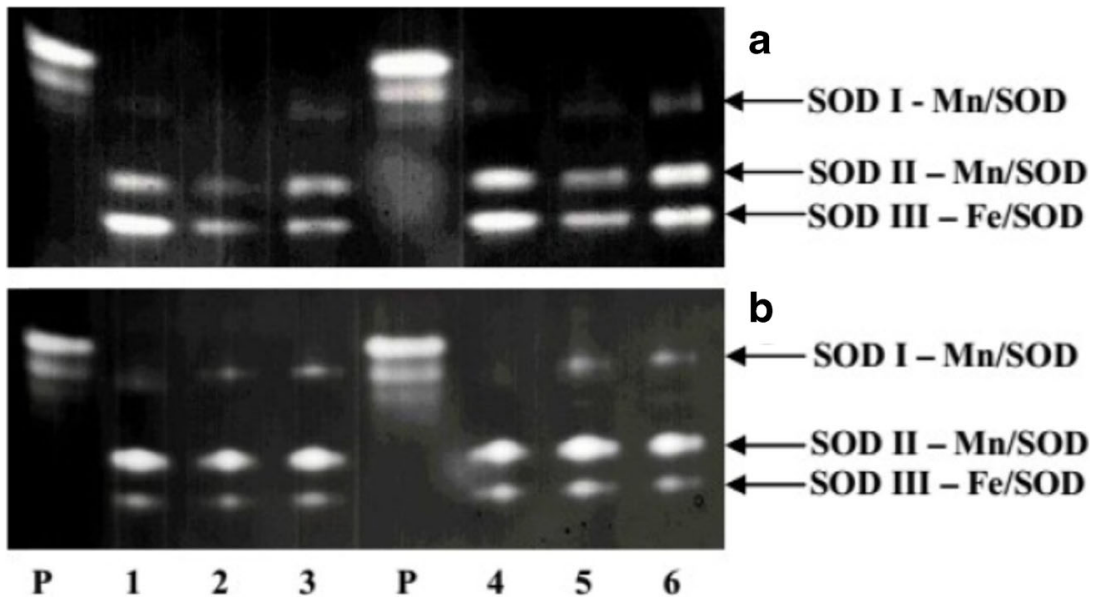

Fig. 4 Superoxide dismutase (SOD) activity staining following nondenaturing polyacrylamide gel electrophoresis of shoots (a) and roots (b) extracts isolated from Micro-Tom (MT) and sitiens (sit) plants grown over a 96-h period in the presence of 10 and $100 \mu \mathrm{M} \mathrm{CdCl}_{2}$ or not treated

$(0 \mu \mathrm{M})$. The lanes listed are: $(P)$ bovine SOD standard, (1) MT $0 \mu \mathrm{M}$ $\mathrm{CdCl}_{2}$, (2) MT $10 \mu \mathrm{M} \mathrm{CdCl}_{2}$, (3) MT $100 \mu \mathrm{M} \mathrm{CdCl}_{2}$, (4) sit $0 \mu \mathrm{M} \mathrm{CdCl}_{2}$, (5) sit $10 \mu \mathrm{M} \mathrm{CdCl}_{2}$, (6) sit $100 \mu \mathrm{M} \mathrm{CdCl}_{2}$ 
Fig. 5 Total activity $\left(\mu \mathrm{mol} \mathrm{min}^{-1}\right.$ $\mathrm{mg}^{-1}$ protein) of Catalase (CAT) in roots (a) and shoots (b) of Micro-Tom (MT) and sitiens (sit) plants; glutathione reductase (GR) in roots (c) and shoots (d) of MT and sit plants; and ascorbate peroxidase (APX) in roots (e) and shoots (f) of MT and sit plants grown over a $96-\mathrm{h}$ period in the presence of 10 and $100 \mu \mathrm{M}$ $\mathrm{CdCl}_{2}$ or not treated $(0 \mu \mathrm{M})$. Values are the means of three replicates \pm SE. Different letters indicate significant difference at $p<0.05$
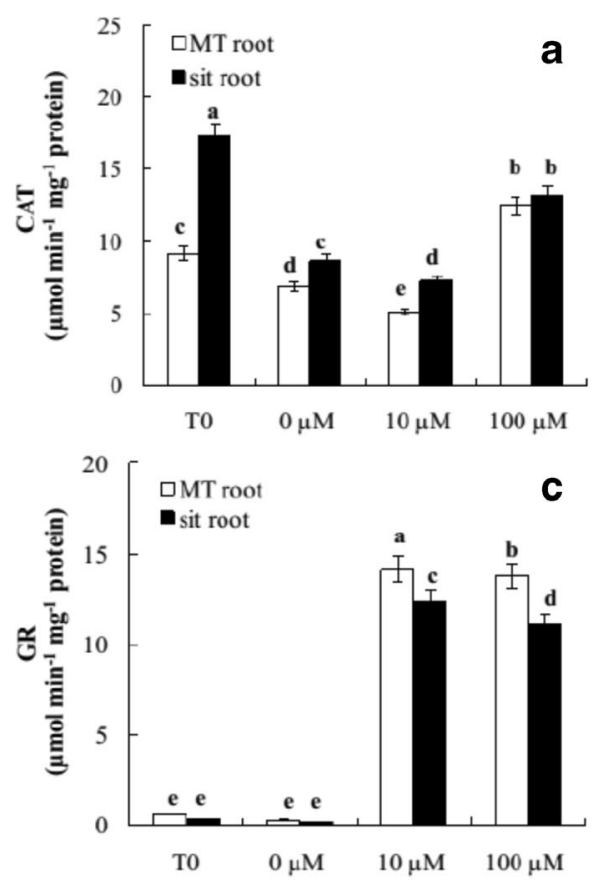

$\square$ MT shoot
- sit shoot

b

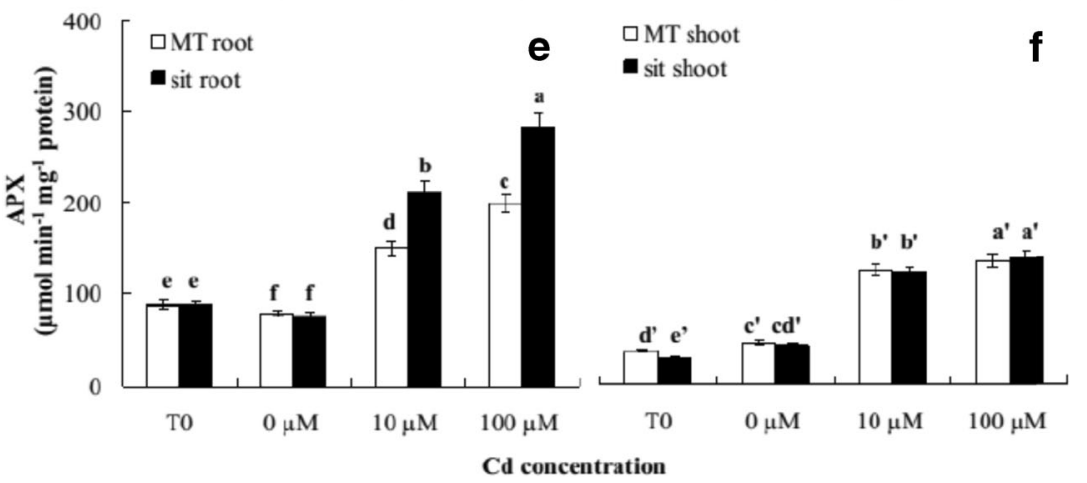

disorganized, and the chloroplasts were malformed, whereas in the control leaves the chloroplasts had a normal shape and contained well-compartmentalized grana and organized thylakoids (Fig. 9a, d).
Fig. 6 Leaf cross-sections of Micro-Tom (MT) and sit mutant grown in nutrient solution with 10 and $100 \mu \mathrm{M} \mathrm{CdCl}_{2}$, or not treated $(0 \mu \mathrm{M})$, observed by light microscopy. a-c Leaves of MT: $0 \mu \mathrm{M} \mathrm{CdCl}_{2}(\mathbf{a}), 10 \mu \mathrm{M} \mathrm{CdCl}_{2}$ (b), $100 \mu \mathrm{M} \mathrm{CdCl}_{2}$ (c). d-f Leaves of sit: $0 \mu \mathrm{M} \mathrm{CdCl}_{2}$ (d), $10 \mu \mathrm{M} \mathrm{CdCl}_{2}$ (e), $100 \mu \mathrm{M} \mathrm{CdCl}_{2}$ (f). $e$, epidermis; $p$, palisade parenchyma; $s$ : spongy parenchyma; asterisks indicate intercellular space. Scale bar $=100 \mu \mathrm{m}$

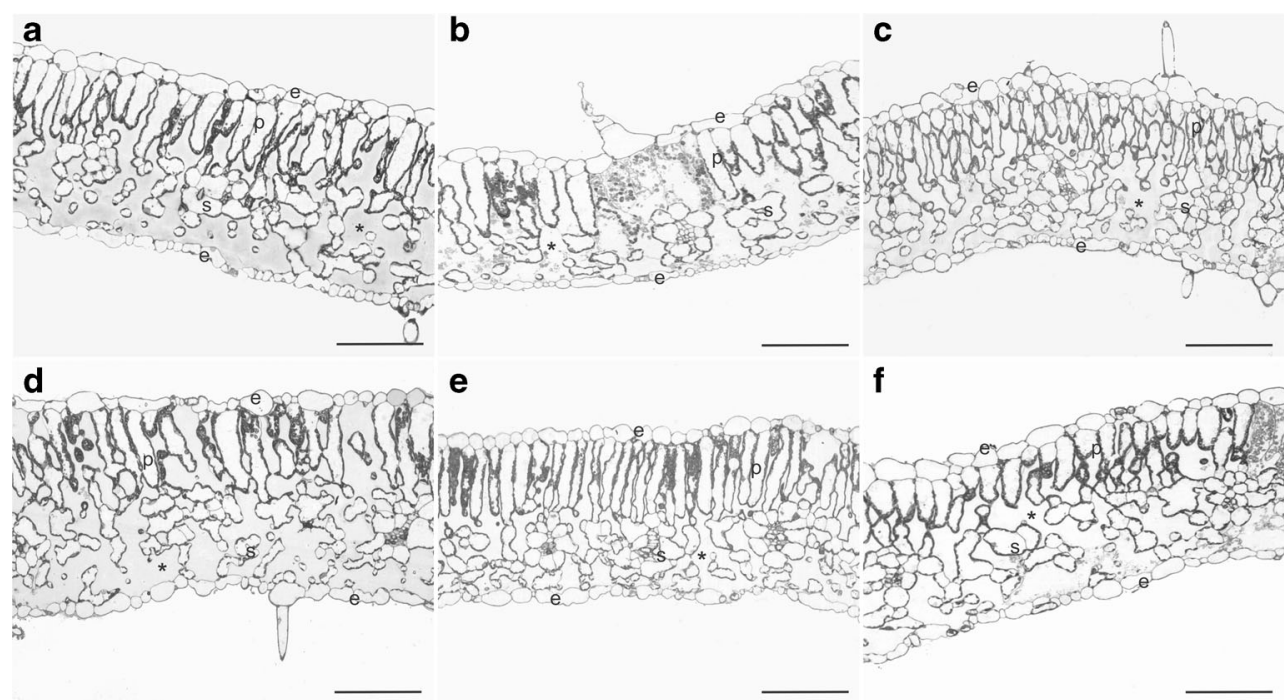


Fig. 7 Micro-Tom (MT) and sit mutant roots of plants grown in nutrient solution with 0,10 , or $100 \mu \mathrm{M} \mathrm{CdCl}_{2}$, observed in cross-sections by light microscopy. a-c MT: $0 \mu \mathrm{M}$ $\mathrm{CdCl}_{2}(\mathbf{a}) ; 10 \mu \mathrm{M} \mathrm{CdCl}_{2}(\mathbf{b})$; $100 \mu \mathrm{M} \mathrm{CdCl}_{2}$ (c); d-f sit: $0 \mu \mathrm{M}$ $\mathrm{CdCl}_{2}$ (d); $10 \mu \mathrm{M} \mathrm{CdCl}_{2}(\mathbf{e})$; $100 \mu \mathrm{M} \mathrm{CdCl}_{2}$ (f).e e epidermis; $c$, cortex; $v$, vascular cylinder. Scale bar $=100 \mu \mathrm{m}$
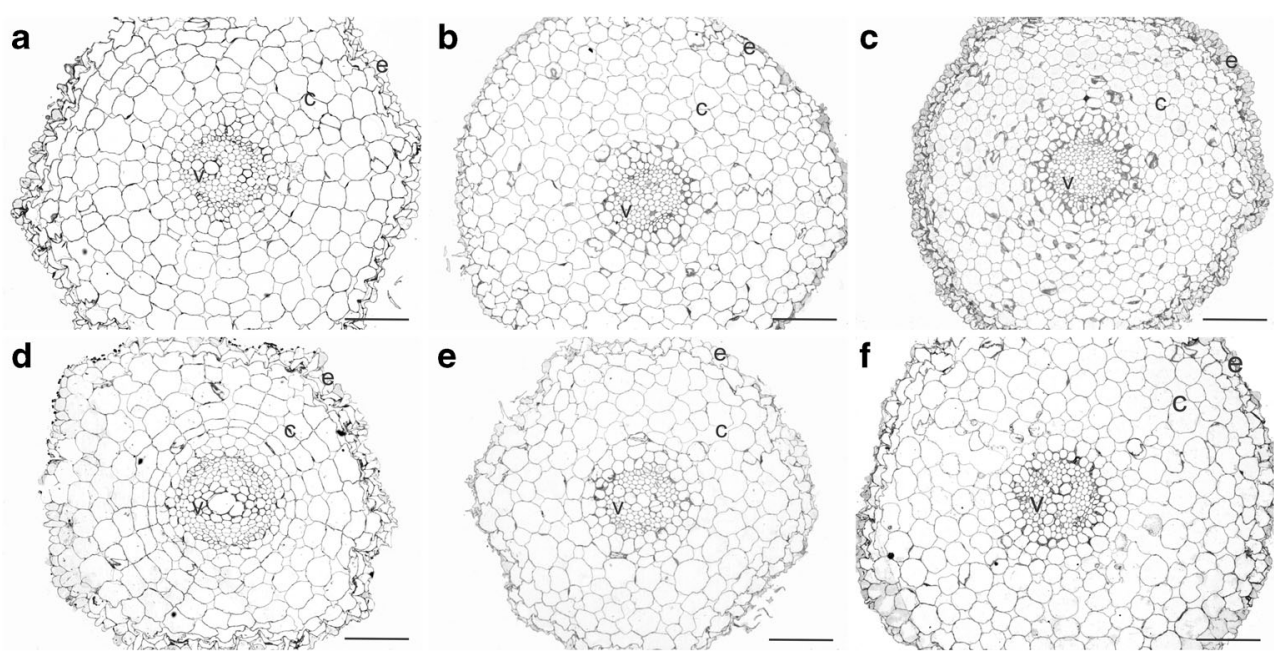

\section{Discussion}

Although research carried out in recent years has shown that all hormonal classes have important roles in abiotic stress response, $\mathrm{ABA}$ is a fundamental molecule that strongly regulates the outcome of the interaction between plants and a harmful environment. It has been shown that the mechanisms by which ABA regulates stress responses involve many molecular, biochemical and morpho-anatomical changes (Hong et al. 2013; Kim 2014). In other words, ABA is part of the stress response, which involves multiple and complex events, especially when different abiotic stresses are considered. Thus, in order to further elucidate the roles of ABA during $\mathrm{Cd}$ stress response in tomato, the ABA-deficient sit mutant was used and exposed to concentrations of 0,10 , and $100 \mu \mathrm{M} \mathrm{CdCl}_{2}$ over a 96-h period in a hydroponic system and biochemical, physiological and anatomical responses were analyzed. Moreover, the sit mutant has not yet been fully characterized and has the potential to help unraveling the roles of ABA on abiotic stresses.

In tomato, ABA plays a multifaceted role when water, salinity, nutrient, and temperature stresses occur, including adjustment mechanisms of stress tolerance (Hermans et al. 2010; An et al. 2014; Osakabe et al. 2014). Under Cd stress, the ABA-deficient sit mutant exhibited multiple stress responses, which appears to be dependent upon the plant tissue or $\mathrm{Cd}$ concentration. Indeed, while the wild-type (MT) counterpart exhibited enhanced root dry weight at $100 \mu \mathrm{M} \mathrm{CdCl}_{2}$, and shoot dry weight when grown in both $\mathrm{Cd}$ concentrations chosen for the experiments, the dry weight in roots and shoots of the sit mutant did not differ from the control and was considerably lower than in MT (Fig. 1a, b). These results may be, at least in part, explained by the natural reduced growth shown by sit due to its ABA deficiency (Carvalho et al. 2011). However, it is interesting to note that sit accumulated higher Cd amounts in the root when compared to MT (Fig. 1c), whereas in the shoot there was no difference between MT and the mutant (Fig. 1d), indicating different rates of Cd translocation among plant organs between the two genotypes. Thus, $\mathrm{Cd}$ accumulation in sit may not explain the reduced growth of roots, but it seems that there is a signaling between root and shoot, which is dependent upon ABA since a progressive increase in dry weight was not observed in sit. In fact, this may be reinforced by the similar Cd accumulation in MT and sit shoots.

Considering the increase in dry weight observed in MT from 0 to $100 \mu \mathrm{M} \mathrm{CdCl}_{2}$, it is not surprising that small concentrations of toxic elements appear to stimulate growth. In fact, the growth stimulus in the presence of $\mathrm{Cd}$ has previously been observed in in vitro cell culture of sugarcane (Fornazier et al. 2002), mycelium of Aspergillus nidulans (Guelfi et al. 2003), coffee suspension cells (Gomes-Junior et al. 2006), tobacco BY-2 cells (Gratão et al. 2008a), and also in tomato plants (Gratão et al. 2008b; Zhu et al. 2011). This hormetic mechanism by which $\mathrm{Cd}$ induces growth is still poorly understood, but the absence of dry weight increase observed in the sit mutant, which is ABA deficient, allows us to suggest that this mechanism also appears to be dependent on ABA.

Leaf chlorophyll breakdown is an important catabolic process, which commonly occurs in plants grown under stress, and thus can be used as an important stress indicator (Monteiro et al. 2011). However, we observed that the chlorophyll content was not altered in MT and sit in the presence of Cd (Fig. 2). Accordingly, the presence of $\mathrm{Cd}$ also did not negatively impact the growth of MT and sit plants (Fig. 1a, b). This could have occurred by an insufficient period of exposure to the metal, although two concentrations of $\mathrm{Cd}$ were used, which were high enough to accumulate $\mathrm{Cd}$ in the roots and shoots, at least at $100 \mu \mathrm{M} \mathrm{CdCl}_{2}$, and to induce oxidative stress changes. As a matter of fact, an induction of lipid peroxidation, measured by changes in MDA levels, can be observed in roots (Fig. 3a) and shoots (Fig. 3b) from 10 to $100 \mu \mathrm{M} \mathrm{CdCl}_{2}$ in both MT and sit, 
Fig. 8 Ultrastructure effect of cadmium on root tip cells of Micro-Tom (MT) and sit mutant plants grown in nutrient solution with and without $\mathrm{CdCl}_{2}$. a-f plants of MT; $\mathbf{g}-\mathbf{l}$ plants of sit. $\mathbf{a}$, $\mathbf{d}, \mathbf{g}, \mathbf{j}=0 \mu \mathrm{M} \mathrm{CdCl}_{2} ; \mathbf{b}, \mathbf{e}, \mathbf{h}$, $\mathbf{k}=10 \mu \mathrm{M} \mathrm{CdCl}_{2}$ and $\mathbf{c}, \mathbf{f}, \mathbf{i}$, $\mathbf{l}=100 \mu \mathrm{M} \mathrm{CdCl}_{2}$. Note the increase in number of

mitochondria $(\mathbf{b}, \mathbf{c}, \mathbf{e}, \mathbf{f}, \mathbf{i}, \mathbf{l})$ and increase of vacuoles $(\mathbf{e}, \mathbf{f})$. Arrows indicate mitochondria, $n$, nucleus; $c$, cell wall; $m$, mitochondria; $v$, vacuole. Scale bars: a, c, $\mathbf{g}$, $\mathbf{i}=500 \mu \mathrm{m} ; \mathbf{b}, \mathbf{h}=1000 \mu \mathrm{m} ; \mathbf{d}, \mathbf{e}$, $\mathbf{j}, \mathbf{k}=5 \mu \mathrm{m} ; \mathbf{f}, \mathbf{k}=2.5 \mu \mathrm{m}$
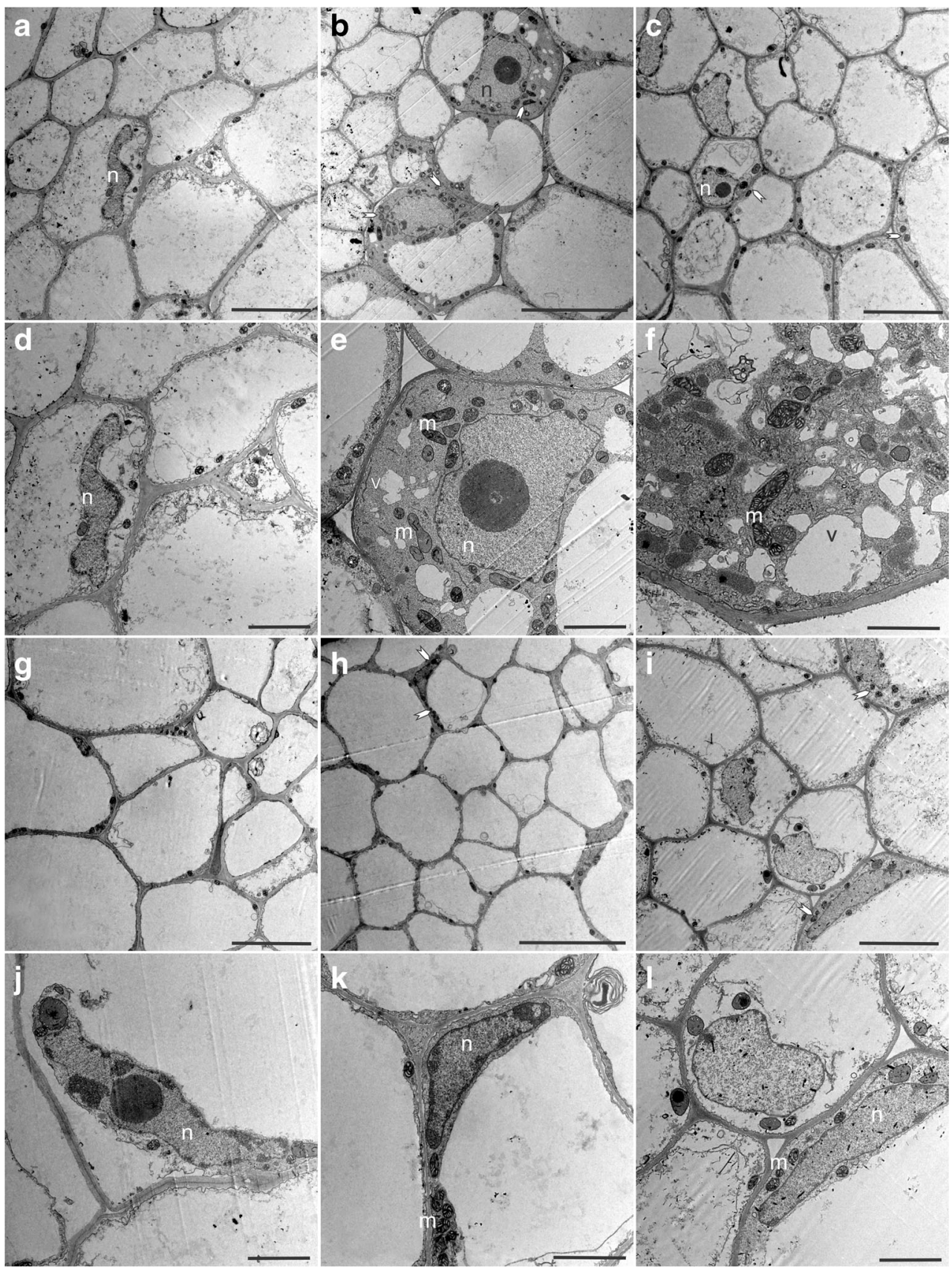

being more pronounced in the roots of the mutant. These results indicate that although $\mathrm{Cd}$ treatments did not alter growth (Fig. 1a, b) or chlorophyll content (Fig. 2) in these genotypes, the accumulation of $\mathrm{Cd}$ in the roots, and in a lesser extent in shoots, induced lipid peroxidation in these organs. Moreover, an enhanced MDA accumulation in the roots of sit treated with $\mathrm{CdCl}_{2}$ was clearly observed, suggesting that ABA deficiency amplifies the stress response to $\mathrm{Cd}$. In other words, the enhanced MDA in sit could be attributed to a negative effect of $\mathrm{ABA}$ on lipid peroxidation, which seems to be true only for metal stress response, because the natural ABA deficiency in the mutant did not alter MDA under control conditions (without Cd) (Fig. 3), as previously reported in tomato (Monteiro et al. 2012).

In the presence of $\mathrm{Cd}$ an increase in $\mathrm{H}_{2} \mathrm{O}_{2}$ accumulation in roots of MT and sit (Fig. 3c, d) was observed, whereas the increase in shoots seems to be associated to time since the increase in $\mathrm{H}_{2} \mathrm{O}_{2}$ occurred between treatments without $\mathrm{Cd}$ $\left.(0 \mu \mathrm{M} \mathrm{CdCl})_{2}\right)$, when compared to T0. The enhanced MDA content may be in part due to the accumulation of $\mathrm{H}_{2} \mathrm{O}_{2}$, but that is not dependent on ABA since the $\mathrm{H}_{2} \mathrm{O}_{2}$ content in the mutant did not differ from MT. 
Fig. 9 Effect of cadmium on chloroplast ultrastructure of Micro-Tom (MT) and sit mutant plants grown in nutrient solution with 0,10 and $100 \mu \mathrm{M} \mathrm{CdCl}_{2}$. a-c plants of MT: $0 \mu \mathrm{M} \mathrm{CdCl}_{2}$ (a), $10 \mu \mathrm{M} \mathrm{CdCl}_{2}$ (b), $100 \mu \mathrm{M}$ $\mathrm{CdCl}_{2}$ (c); d-f plants of sit: $0 \mu \mathrm{M}$ $\mathrm{CdCl}_{2}$ (d), $10 \mu \mathrm{M} \mathrm{CdCl}_{2}$ (e), $100 \mu \mathrm{M} \mathrm{CdCl}$ (f). $c$, chloroplast; $g$, grana; $s$, starch grain; $m$, mitochondria, $t$, thylakoids. Scale bars: $\mathbf{a}, \mathbf{b}, \mathbf{e}=2 \mu \mathrm{m} ; \mathbf{c}, \mathbf{d}, \mathbf{f}=5 \mu \mathrm{m}$
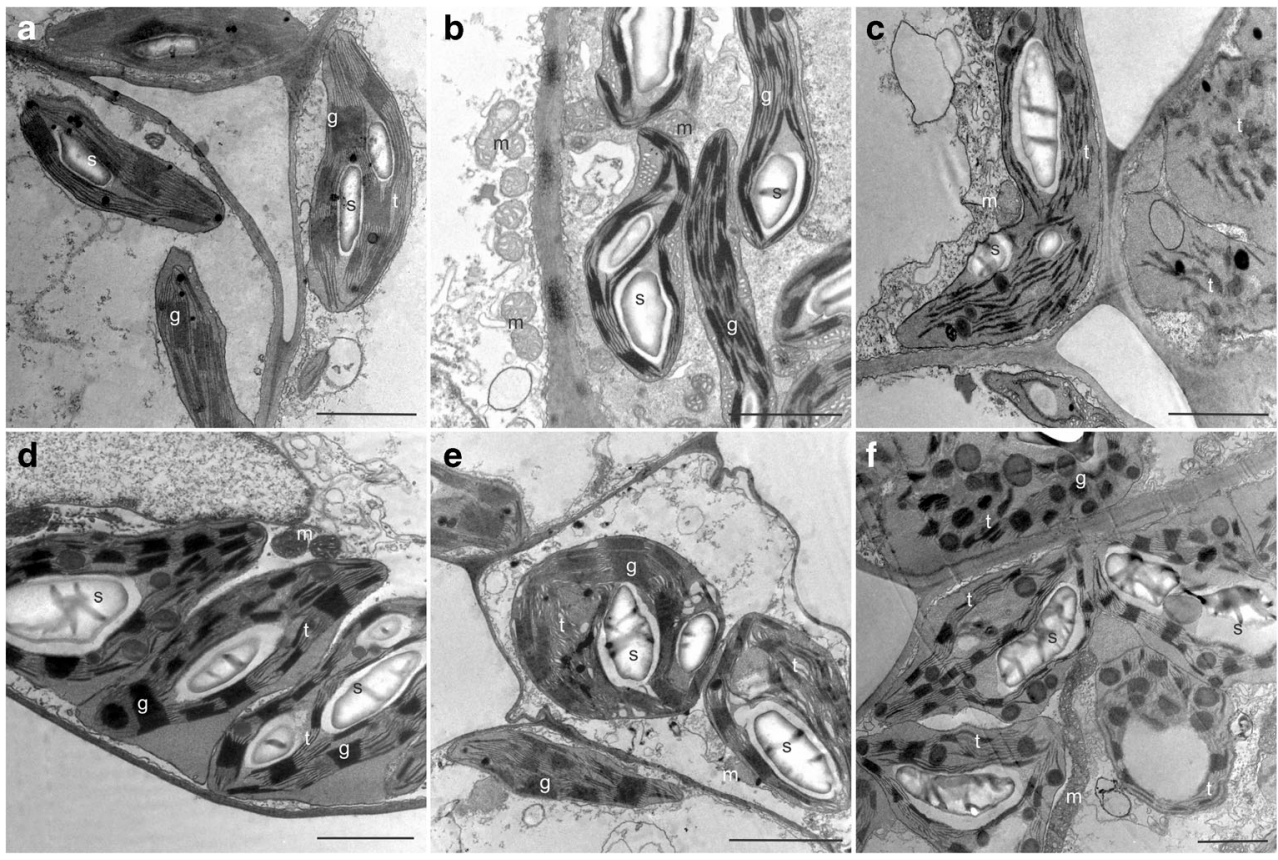

Regarding enzyme peroxidase activity, which can reduce $\mathrm{H}_{2} \mathrm{O}_{2}$, the data showing that a higher activity of CAT and APX, and reduction of $\mathrm{H}_{2} \mathrm{O}_{2}$ and MDA in roots of MT and sit grown from $\mathrm{T} 0$ to $10 \mu \mathrm{M} \mathrm{CdCl}_{2}$, are taken together. When comparing time and $\mathrm{CdCl}_{2}$ concentration, the enhanced CAT activity in roots (Fig. 5a) can be associated to reduced MDA and $\mathrm{H}_{2} \mathrm{O}_{2}$ (Fig. 3a). However, at $100 \mu \mathrm{M} \mathrm{CdCl}_{2}$, this was not the case, most likely because a burst of oxidative stress was triggered in the roots, inducing strong lipid peroxidation and antioxidant enzyme activities such as for GR (Fig. 5c) and APX (Fig. 5e). Moreover, compared to MT, the exposure to $\mathrm{Cd}$ did not alter SOD total activity in roots (Fig. 4a, b), indicating that the alteration in $\mathrm{H}_{2} \mathrm{O}_{2}$ does not appear to be associated with the level of this enzyme by catalyzing the dismutation of superoxide into $\mathrm{H}_{2} \mathrm{O}_{2}$.

Although sit naturally did not exhibit changes in lipid peroxidation when compared to MT (Fig.3a, b), this mutant revealed a multifaceted antioxidant enzyme activity pattern, which was depended upon organ, enzyme, time, and metal concentration (Fig. 5). When compared to MT, sit exhibited enhanced CAT activity with and without Cd (Fig. 5a), whereas GR (Fig. 5d) and APX (Fig. 5e) activities of shoots and roots, respectively, were enhanced in the $\mathrm{Cd}$ treatments. On the other hand, sit exhibited reduced CAT activity in $\mathrm{T} 0$ and $100 \mu \mathrm{M}$ $\mathrm{CdCl}_{2}$ in shoots, and GR activity in 10 and $100 \mu \mathrm{M} \mathrm{CdCl}_{2}$ (Fig. 5c). In general, the high antioxidant activity in sit could be associated to a constitutive ABA deficiency, which results in a phenotypically wilt plant, stunted and epinastic (Tal 1966). Thus, under stressful conditions sit plants exhibit more sensitivity, such as previously shown to salinity (Mäkelä et al. 2003) and water deficit (Thompson et al. 2004), and in this work the mutant was shown to alter the antioxidant response also to the metal treatment. Therefore, it seems clear that a complex biochemical network involves ABA-signaling in metal stress.

In addition, leaves and roots anatomical and ultrastructural changes induced by $\mathrm{Cd}$ were also observed. The most evident response was the reduction in sit and MT of leaf intercellular space, cell area and size (Fig. 6b, c, e, f), as well as structural abnormalities in vacuoles (Fig. 8e, f) and mitochondria (Fig. 8b, c, e, f, k, l) in roots, and in chloroplasts (Fig. 9b, c, e), an expected outcome also previously reported in response to Cd stress (Daud et al. 2009; Gratão et al. 2009). On the other hand, root cell size was reduced in both MT and sit (Fig. 7b, c, e, f). Hence, even showing a strong accumulation of $\mathrm{Cd}$ in $100 \mu \mathrm{M} \mathrm{CdCl}_{2}$ (Fig. 1c) and increasing lipid peroxidation (Fig. 3a), sit does not show a reduction in root cell size (Fig. 7). Yet, these results do not confer more Cd tolerance to sit because MT and the mutant did not present reduced growth from 0 to $100 \mu \mathrm{M} \mathrm{CdCl}{ }_{2}$.

In this work, we initially hypothesized that $\mathrm{ABA}$ is part of the $\mathrm{Cd}$ stress signaling in tomato, and to test that we submitted the ABA-deficient mutant sit to 0,10 , and $100 \mu \mathrm{M} \mathrm{CdCl}_{2}$. The results suggest a confirmation of our hypothesis, with a clear important role of $\mathrm{ABA}$ on $\mathrm{Cd}$ stress signaling in tomato. In fact, the mutant accumulated more $\mathrm{Cd}$ in the roots when compared to its wild-type counterpart MT. In other words, ABA production seems to be related to a decrease in Cd accumulation in this plant species. Wang et al. (2016) using two Solanum photeinocarpum ecotypes (mining and farmland) applied exogenous ABA, which resulted in increased Cd content in both ecotypes. Although the interaction between ABA and $\mathrm{Cd}$ seems dependent on the plant species, exogenous ABA application can act differently from $\mathrm{ABA}$ production 
under $\mathrm{Cd}$ treatment. This observation is also supported by previous reports in which ABA content rapidly increased in the leaves and roots in the rice Cd-tolerant cultivar (cv. Tainung 67, TNG67), but not in the Cd-sensitive cultivar (cv. Taichung Native 1, TN1) (Hsu and Kao 2003). Additionally, a molecular mechanism of interaction between $\mathrm{Cd}$ and ABA has been clarified in Arabidopsis, with a decrease in $\mathrm{Cd}$ accumulation in the presence of exogenous ABA, by inhibiting the IRON-REGULATED TRANSPORTER 1 (IRT1) (Fan et al. 2014), a broadspectrum transporter in roots, which is involved in the absorption of several other divalent cations, including $\mathrm{Cd}$ (Vert et al. 2002). Additionally, we have been able to show that the mechanisms by which ABA interacts with $\mathrm{Cd}$ is followed by evident histological and biochemical alterations. Although we found some evidence that $\mathrm{Cd}$ stress response is mediated by ABA in tomato, the use of an ABA-deficient mutant to study the role of this hormone in plants grown under stress can be complex because of their natural adverse water relations and altered growth (Thompson et al. 2004). Ongoing research is being carried out, in which sit and other hormonal mutants such as Never ripe and diageotropica have been subjected to combined stresses such as water deficit and metal to further elucidate the role of ABA signaling, and the involvement of other hormones in response to stress.

Acknowledgments This work was funded by Fundação de Amparo à Pesquisa do Estado de São Paulo (FAPESP — grants 2009/54676-0 and 2011/50982-9). R.A.A. and A.P.M. thank Conselho Nacional de Desenvolvimento Científico e Tecnológico (CNPq-Brazil) for the research fellowships. The authors also acknowledge "Centro de Microscopia e Imagem”, FOP/UNICAMP, and LBCM/CENA, for maintaining the electron and light microscopes, respectively.

\section{Compliance with ethical standards}

Conflict of interest The authors declare no competing financial interests or conflict of interest.

\section{References}

Alcântara BK, Machemer-Noonan K, Silva Júnior FG, Azevedo RA (2015) Dry priming of maize seeds reduces aluminum stress. Plos One 10(12):e0145742. doi:10.1371/journal.pone.0145742

Ali B, Huang CR, Qi ZY, Ali S, Daud MK, Geng XX, Liu HB, Zhou WJ (2013a) 5-Aminolevulinic acid ameliorates cadmium-induced morphological, biochemical, and ultrastructural changes in seedlings of oilseed rape. Environ Sci Pollut Res 20:7256-7267. doi:10.1007/ s11356-013-1735-5

Ali B, Tao Q, Zhou Y, Gill RA, Ali S, Rafiq MT, Xu L, Zhou W (2013b) 5-Aminolevolinic acid mitigates the cadmium-induced changes in Brassica napus as revealed by the biochemical and ultra-structural evaluation of roots. Ecotoxicol Environ Saf 92:271-280. doi:10. 1016/j.ecoenv.2013.02.006
Al-Khateeb W, Al-Qwasemeh H (2014) Cadmium, copper and zinc toxicity effects on growth, proline content and genetic stability of Solanum nigrum L. a crop wild relative for tomato; comparative study. Physiol Mol Biol Plants 20:31-39. doi:10.1007/s12298013-0211-5

An Y, Zhou P, Liang J (2014) Effects of exogenous application of abscisic acid on membrane stability, osmotic adjustment, photosynthesis and hormonal status of two Lucerne (Medicago sativa L.) genotypes under high temperature stress and drought stress. Crop Pasture Sci 65:274-286. doi:10.1071/cp13162

Arruda SCC, Barbosa HS, Azevedo RA, Arruda MAZ (2013) Comparative studies focusing on transgenic through cp4EPSPS gene and non-transgenic soybean plants: an analysis of protein species and enzymes. J Proteom 93:107-116. doi:10.1016/j.jprot.2013. 05.039

Arruda SCC, Silva ALD, Galazzi RM, Azevedo RA, Arruda MAZ (2015) Nanoparticles applied to plant science: a review. Talanta 131:693-705. doi:10.1016/j.talanta.2014.08.050

Asgher M, Khan MIR, Anjum NA, Khan NA (2015) Minimising toxicity of cadmium in plants-role of plant growth regulators. Protoplasma 252:399-413. doi:10.1007/s00709-014-0710-4

Azevedo RA, Carvalho RF, Cia MC, Gratão PL (2011) Sugarcane under pressure: an overview of biochemical and physiological studies of abiotic stress. Trop Plant Biol 4:42-51. doi:10.1007/s12042-0119067-4

Barbosa HS, Arruda SCC, Azevedo RA, Arruda MAZ (2012) New insights on proteomics of transgenic soybean seeds: evaluation of differential expressions of enzymes and proteins. Anal Bioanal Chem 402:299-314. doi:10.1007/s00216-011-5409-1

Bradford MM (1976) A rapid and sensitive method for quantification of microgram quantities of protein utilizing the principle of protein-dye binding. Anal Biochem 72:248-254. doi:10.1016/0003-2697(76) 90527-3

Cai BD, Yin J, Hao YH, Li YN, Yuan BF, Feng YQ (2015) Profiling of phytohormones in rice under elevated cadmium concentration levels by magnetic solid-phase extraction coupled with liquid chromatography tandem mass spectrometry. J Chromatogr A 1406:78-86. doi: 10.1016/j.chroma.2015.06.046

Carvalho RF, Campos ML, Pino LE, Crestana SL, Zsögön A, Lima JE, Benedito VA, Peres LEP (2011) Convergence of developmental mutants into a single tomato model system: 'Micro-Tom' as an effective toolkit for plant development research. Plant Methods 7: 18. doi:10.1186/1746-4811-7-18

Carvalho RF, Monteiro CC, Caetano AC, Dourado MN, Gratão PL, Haddad CKB, Peres LEP, Azevedo RA (2013) Leaf senescence in tomato mutants as affected by irradiance and phytohormones. Biol Plant 57:749-757. doi:10.1007/s10535-013-0333-1

Cutler SR, Rodriguez PL, Finkelstein RR, Abrams SR (2010) Abscisic acid: emergence of a core signaling network. Annu Rev Plant Biol 61:651-679. doi:10.1146/annurev-arplant-042809-112122

Cuypers A, Plusquin M, Remans T, Jozefczak M, Keunen E, Gielen H, Opdenakker K, Nair AR, Munters E, Artois TJ, Nawrot T, Vangronsveld J, Smeets K (2010) Cadmium stress: an oxidative challenge. Biometals 23:927-940. doi:10.1007/s10534-010-9329-X

Daud MK, Sun Y, Dawood M, Hayat Y, Variath MT, Wu YX, Raziuddin, Mishkat U, Salahuddin, Najeeb U, Zhu S (2009) Cadmium-induced functional and ultrastructural alterations in roots of two transgenic cotton cultivars. J Hazard Mater 161:463-473. doi:10.1016/j. jhazmat.2008.03.128

Djebali W, Zarrouk M, Brouquisse R, El Kahoui S, Limam F, Ghorbel MH, Chaibi W (2005) Ultrastructure and lipid alterations induced by cadmium in tomato (Lycopersicon esculentum) chloroplast membranes. Plant Biol 7:358-368. doi:10.1055/s-2005-837696

Dourado MN, Martins PF, Quecine MC, Piotto FA, Souza LA, Franco MR, Tezotto T, Azevedo RA (2013) Burkholderia sp. SCMS54 
reduces cadmium toxicity and promotes growth in tomato. Ann Appl Biol 163:494-507. doi:10.1111/aab.12066

Dourado MN, Franco MR, Peters LP, Martins PF, Souza LA, Piotto FA, Azevedo RA (2015) Antioxidant enzymes activities of Burkholderia ssp. strains-oxidative responses to Ni toxicity. Environ Sci Pollut Res 22:19922-19932. doi:10.1007/s11356-015-5204-1

Fan SK, Fang XZ, Guan MY, Ye YQ, Lin XY, Du ST, Jin CW (2014) Exogenous abscisic acid application decreases cadmium accumulation in Arabidopsis plants, which is associated with the inhibition of IRT1-mediated cadmium uptake. Front Plant Sci 5:1-8. doi:10. 3389/fpls.2014.00721

Fornazier RF, Ferreira RR, Vitoria AP, Molina SMG, Lea PJ, Azevedo RA (2002) Effects of cadmium on antioxidant enzyme activities in sugar cane. Biol Plant 45:91-97

Gallego SM, Pena LB, Barcia RA, Azpilicueta CE, Iannone MF, Rosales EP, Zawoznik MS, Groppa MD, Benavides MP (2012) Unravelling cadmium toxicity and tolerance in plants: insight into regulatory mechanisms. Environ Exp Bot 83:33-46. doi:10.1016/j.envexpbot. 2012.04.006

Gill SS, Khan NA, Tuteja N (2012) Cadmium at high dose perturbs growth, photosynthesis and nitrogen metabolism while at low dose it up regulates sulfur assimilation and antioxidant machinery in garden cress (Lepidium sativum L.). Plant Sci 182:112-120. doi:10. 1016/j.plantsci.2011.04.018

Gomes-Junior RA, Moldes CA, Delite FS, Pompeu GB, Gratão PL, Mazzafera P, Lea PJ, Azevedo RA (2006) Antioxidant metabolism of coffee cell suspension cultures in response to cadmium. Chemosphere 65:1330-1337. doi:10.1016/j.chemosphere.2006.04. 056

Gratão PL, Polle A, Lea PJ, Azevedo RA (2005) Making the life of heavy metal-stressed plants a little easier. Funct Plant Biol 32:481-494. doi:10.1071/FP05016

Gratão PL, Pompeu GB, Capaldi FR, Vitorello VA, Lea PJ, Azevedo RA (2008a) Antioxidant response of Nicotiana tabacum cv. Bright yellow 2 cells to cadmium and nickel stress. Plant Cell Tissue Org 94: 73-83. doi:10.1007/s11240-008-9389-6

Gratão PL, Monteiro CC, Antunes AM, Peres LEP, Azevedo RA (2008b) Acquired tolerance of tomato (Lycopersicum esculentum cv. MicroTom) plants to cadmium-induced stress. Ann Appl Biol 153:321333. doi:10.1111/j.1744-7348.2008.00299.x

Gratão PL, Monteiro CC, Rossi ML, Martinelli AP, Peres LEP, Medici LO, Lea PJ, Azevedo RA (2009) Differential ultrastructural changes in tomato hormonal mutants exposed to cadmium. Environ Exp Bot 67:387-394. doi:10.1016/j.envexpbot.2009.06.017

Gratão PL, Monteiro CC, Carvalho RF, Tezotto T, Piotto FA, Peres LEP, Azevedo RA (2012) Biochemical dissection of diageotropica and Never ripe tomato mutants to Cd-stressful conditions. Plant Physiol Biochem 56:79-96. doi:10.1016/j.plaphy2012.04.009

Gratão PL, Monteiro CC, Tezotto T, Carvalho RF, Alves LR, Peters LP, Azevedo RA (2015) Cadmium stress antioxidant responses and root-to-shoot communication in grafted tomato plants. Biometals 28:803-816. doi:10.1007/s10534-015-9867-3

Guelfi A, Azevedo RA, Lea PJ, Molina SMG (2003) Growth inhibition of the filamentous fungus Aspergillus nidulans by cadmium: an antioxidant enzyme approach. J Gen Appl Microbiol 49:63-73

Han C, Shen HY, Ye J, Yang L, Liang S (2012) Effect of exogenous abscisic acid on tolerance of wheat seedlings to cadmium stress. Acta Botan Boreali-Occiden Sin 32:745-750, http://en.cnki.com. cn/Article en/CJFDTotal-DNYX201204017.htm. Accessed 12 October 2015

Harrison E, Burbidge A, Okyere JP, Thompson AJ, Taylor IB (2011) Identification of the tomato ABA-deficient mutant sitiens as a member of the ABA-aldehyde oxidase gene family using genetic and genomic analysis. Plant Growth Regul 64:301-309. doi:10.1007/ s10725-010-9550-1
Hartung W, Schraut D, Jiang F (2005) Physiology of abscisic acid (ABA) in roots under stress - a review of the relationship between root $\mathrm{ABA}$ and radial water and ABA flows. Aust J Agric Res 56: 1253-1259. doi:10.1071/AR05065

Hermans C, Vuylsteke M, Coppens F, Craciun A, Inzé D, Verbruggen N (2010) Early transcription changes induced by magnesium deficiency in Arabidopsis thaliana reveal the alteration of circadian clock gene expression in roots and the triggering of abscisic acidresponsive genes. New Phytol 187:119-131. doi:10.1111/j.14698137.2010.03258.x

Hippler FWR, Boaretto RM, Quaggio JA, Azevedo RA, Mattos D (2015) Towards soil management with $\mathrm{Zn}$ and $\mathrm{Mn}$ : estimates of fertilization efficacy of citrus trees. Ann Appl Biol 166:484-495. doi:10.1111/ aab.12197

Hoagland D, Arnon D (1950) The water-culture method for growing plants without soil. Circular. California Agricultural Berkeley: University of California, College of Agriculture, Agricultural Experiment Station, Berkeley

Hong JH, Seah SW, Xu J (2013) The root of ABA action in environmental stress response. Plant Cell Rep 32:971-983. doi:10.1007/s00299013-1439-9

Hsu YT, Kao CH (2003) Role of abscisic acid in cadmium tolerance of rice (Oryza sativa L.) seedlings. Plant Cell Environ 26:867-874. doi:10.1046/j.1365-3040.2003.01018.x

Hu YF, Zhou G, Na XF, Yang L, Nan WB, Liu X, Zhang YQ, Li JL, Bi YR (2013) Cadmium interferes with maintenance of auxin homeostasis in Arabidopsis seedlings. J Plant Physiol 170:965-975. doi: 10.1016/j.jpiph.2013.02.008

Iannone MF, Groppa MD, Benavides MP (2015) Cadmium induces different biochemical responses in wild type and catalase-deficient tobacco plants. Environ Exp Bot 109:201-211. doi:10.1016/j. envexpbot.2014.07.008

Karnovsky MJ (1965) A formaldehyde-glutaraldehyde fixative of high osmolarity for use in electron microscopy. J Cell Biol 27:137-138

Kim TH (2014) Mechanism of ABA signal transduction: agricultural highlights for improving drought tolerance. J Plant Biol 57:1-8. doi:10.1007/s12374-014-0901-8

López-Chuken UJ, Young SD (2010) Modelling sulphate-enhanced cadmium uptake by Zea mays from nutrient solution under conditions of constant free $\mathrm{Cd}^{2+}$ ion activity. J Environ Sci 22:1080-1085. doi: 10.1016/S1001-0742(09)60220-5

Lux A, Vaculík M, Martinka M, Lišková D, Kulkarni MG, Stirk WA, Van Staden J (2011) Cadmium induces hypodermal periderm formation in the roots of the monocotyledonous medicinal plant Merwilla plumbea. Ann Bot 107:285-292. doi:10.1093/aob/mcq240

Mäkelä P, Munns R, Colmer TD, Peltonen-Sainio P (2003) Growth of tomato and an ABA-deficient mutant (sitiens) under saline conditions. Physiol Plant 117:58-63. doi:10.1034/j.1399-3054.2003. 1170107.x

Maksimović JD, Bogdanović J, Maksimović V, Nikolic M (2007) Silicon modulates the metabolism and utilization of phenolic compounds in cucumber (Cucumis sativus L.) grown at excess manganese. J Plant Nutr Soil Sci 170:739-744. doi:10.1002/jpln.200700101

Malavolta E, Vitti GC, Oliveira SA (1997) Assessment of nutritional status of plants: principles and applications, 2nd edn. Associação Brasileira para Pesquisa da Potassa e do Fosfato, Piracicaba, 319p

Mondal NK, Das C, Roy S, Datta JK, Banerjee A (2013) Effect of varying cadmium stress on chickpea (Cicer arietinum L.) seedlings: an ultrastructural study. Ann Environ Sci 7:59-70, http://hdl.handle. net/2047/d20018674

Monteiro CC, Carvalho RF, Gratão PL, Carvalho G, Tezotto T, Medici LO, Peres LEP, Azevedo RA (2011) Biochemical responses of the ethylene-insensitive Never ripe tomato mutant subjected to cadmium and sodium stresses. Environ Exp Bot 71:306-320. doi:10.1016/ j.envexpbot.2010.12.020 
Monteiro CC, Rolão MB, Franco MR, Peters LP, Cia MC, Capaldi FR, Carvalho RF, Gratão PL, Rossi ML, Martinelli AP, Peres LEP, Azevedo RA (2012) Biochemical and histological characterization of tomato mutants. An Acad Bras Cienc 84:573-585. doi:10.1590/ S0001-37652012005000022

Moradi L, Ehsanzadeh P (2015) Effects of Cd on photosynthesis and growth of safflower (Carthamus tinctoruis L.) genotypes. Photosynthetica 53:506-518. doi:10.1007/s11099-015-0150-1

Nogueirol RC, Monteiro FA, Gratão PL, Borgo L, Azevedo RA (2015) Tropical soils with high aluminum concentrations cause oxidative stress in two tomato genotypes. Environ Monit Assess 187:73. doi: 10.1007/s10661-015-4282-3

Osakabe Y, Yamaguchi-Shinozaki K, Shinozaki K, Tran LSP (2014) ABA control of plant macroelement membrane transport systems in response to water deficit and high salinity. New Phytol 202:3549. doi:10.1111/nph.12613

Peters LP, Carvalho G, Martins PF, Dourado MN, Vilhena MB, Pileggi M, Azevedo RA (2014) Differential responses of the antioxidant system of ametryn and clomazone tolerant bacteria. Plos ONE 9: e112271. doi:10.1371/journal.pone.0112271

Piotto FA, Tulmann-Neto A, Franco MR, Boaretto LF, Azevedo RA (2014) Rapid screening for selection of heavy metal-tolerant plants. Crop Breed Appl Biotechnol 14:1-7. doi:10.1590/S198470332014000100001

Rendón MY, Gratão PL, Salva TJG, Azevedo RA, Bragagnolo N (2013) Antioxidant enzyme activity and hydrogen peroxide content during the drying of Arabica coffee beans. Eur Food Res Technol 236:753758. doi:10.1007/s00217-013-1933-x

Reynolds ES (1963) The use of lead citrate at high $\mathrm{pH}$ as an electronopaque stain in electron microscopy. J Cell Biol 17:208-212, http:// www.ncbi.nlm.nih.gov/pubmed/13986422

Schellingen K, Van Der Straeten D, Remans T, Vangronsveld J, Keunen E, Cuypers A (2015) Ethylene signaling is mediating the early cadmium-induced oxidative challenge in Arabidopsis thaliana. Plant Sci 239:137-146. doi:10.1016/j.plantsci2015.07.015

Shekhawat GS, Verma K, Jana S, Singh K, Teotia P, Prasad A (2010) In vitro biochemical evaluation of cadmium tolerance mechanism in callus and seedlings of Brassica juncea. Protoplasma 239:31-38. doi:10.1007/s00709-009-0079-y

Shi WG, Li H, Liu TX, Polle A, Peng CM, Luo ZB (2015) Exogenous abscisic acid alleviates zinc uptake and accumulation in Populus $\times$ canescens exposed to excess zinc. Plant Cell Environ 38:207-223. doi:10.1111/pce.12434

Soares C, Sousa A, Pinto A, Azenha M, Teixeira J, Azevedo RA, Fidalgo F (2016) Effect of 24-epibrassinolide on ROS content, antioxidant system, lipid peroxidation and Ni uptake in Solanum nigrum L. under Ni stress. Environ Exp Bot 122:115-125. doi:10.1016/j. envexpbot.2015.09.010

Stroiński A, Giźewska K, Zielezińska M (2013) Abscisic acid is required in transduction of cadmium signal to potato roots. Biol Plant 57: 121-127. doi:10.1007/s10535-012-0135-X
Su Y, Liu J, Lu Z, Wang X, Zhang Z, Shi G (2014) Effects of iron deficiency on subcellular distribution and chemical forms of cadmium in peanut roots in relation to its translocation. Environ Exp Bot 97:40-48. doi:10.1016/j.envexpbot.2013.10001

Tal M (1966) Abnormal stomatal behavior in wilty mutants of tomato. Plant Physiol 41:1387-1394, http://www.plantphysiol.org/content/ 41/8/1387.full.pdf

Taylor IB, Lineorth RST, Al-Naieb R, Bowman WR, Marples BA (1988) The wilty tomato mutants flacca and sitiens are impaired in the oxidation of ABA-aldedyde to ABA. Plant Cell Environ 11:739745

Thompson AJ, Thorne ET, Burbidge A, Jackson AC, Sharp RE, Taylor IB (2004) Complementation of notabilis, an abscisic acid-deficient mutant of tomato: importance of sequence context and utility of partial complementation. Plant Cell Environ 27:459-471. doi:10. 1111/j.1365-3040.2003.01164.x

Vert G, Grotz N, Dédaldéchamp F, Gaymard F, Guerinot ML, Briat JF, Curie C (2002) IRT1 an Arabidopsis transporter essential for iron uptake from the soil and for plant growth. Plant Cell 14:1223-1233. doi: $10.1105 /$ tpc. 001388

Vitória AP, Lea PJ, Azevedo RA (2001) Antioxidant enzymes responses to cadmium in radish tissues. Phytochemistry 57:701-710

Vitória AP, Da Cunha M, Azevedo RA (2006) Ultrastructural changes of radish leaf exposed to cadmium. Environ Exp Bot 58:47-52. doi:10. 1016/j.envexpbot.2005.06.014

Vitória AP, Rodriguez APM, da Cunha M, Lea PJ, Azevedo RA (2003) Structural changes in radish seedlings exposed to cadmium. Biol Plant 47:561-568. doi:10.1023/B:BIOP. $0000041062.00539 .7 \mathrm{a}$

Wang Y, Wang Y, Kai W, Zhao B, Chen P, Sun L, Ji K, Li Q, Dai S, Sun Y, Wang Y, Pei Y, Leng P (2014) Transcriptional regulation of abscisic acid signal core components during cucumber seed germination and under $\mathrm{Cu}^{2+}, \mathrm{Zn}^{2+}, \mathrm{NaCl}$ and simulated acid rain stress. Plant Physiol Biochem 76:67-76. doi:10.1016/j.plaphy.2014.01.003

Wang J, Lin L, Luo L, Liao M, Lv X, Wang Z, Liang D, Xia H, Wang X, Lai Y, Tang Y (2016) The effects of abscisic acid (ABA) addition on cadmium accumulation of two ecotypes of Solanum photeinocarpum. Environ Monit Assess 188:1-8. doi:10.1007/ s10661-016-5194-6

Wu Z, Zhao X, Sun X, Tan Q, Tang Y, Nie Z, Qu C, Chen Z, Hu C (2015) Antioxidant enzymes systems and the ascorbate-glutathione cycle as contributing factors to cadmium accumulation and tolerance in two oilseed rape cultivars (Brassica napus L.) under moderate cadmium stress. Chemosphere 138:526-536. doi:10.1016/j.chemosphere. 2015.06.080

Zhu XF, Zheng C, Hu YT, Jiang T, Liu Y, Dong NY, Yang JL, Zheng SJ (2011) Cadmium-induced oxalate secretion from root apex is associated with cadmium exclusion and resistance in Lycopersicon esulentum. Plant Cell Environ 34:1055-1064. doi:10.1111/j.13653040.2011.02304.x 